\title{
2 \\ What's travel got to do with it? Exploring a contemporary publishing phenomenon
}

\section{Australian memoirs of living in France}

\section{The boom in the genre}

'Another midlife adventure in the south of France' was the subtitle chosen for classical music broadcaster Christopher Lawrence's memoir Swing Symphony in 2004. 'Just when you thought it was safe to go back in the olive grove' was the tagline on the cover of Bruno Bouchet's parody of the genre, French Letters, from the same year. You could be forgiven for thinking that the surge in publication of books by Australians about life in France had peaked, that the formula was seen as hackneyed, that readers had had their fill. In fact, it was scarcely the beginning for Australian readers and writers; the high tide was still to come.

Although France has long been a popular destination for Australian travellers, ${ }^{1}$ until recently it was not a particularly common subject for their memoirs. Indeed, publicly available memoirs of Australians

1 Although Britain was the primary destination for Australian travellers for most of the nineteenth and twentieth centuries, as Ros Pesman (1996) and Richard White (2013) point out, many also toured the continent. It wasn't until 1980, however, that short-term travel to France by Australian 
in France from the twentieth century are relatively few in number. They cluster around the extraordinary events of the two world wars-the diaries of soldiers and nurses; Nancy Wake's resistance memoir, The White Mouse $^{2}$ — or are the published memoirs of distinguished Australians: Stella Bowen, Rae Johnstone and Gael Elton Mayo. ${ }^{3}$ In these memoirs, France is a backdrop to an extraordinary life, rather than the focus or raison d'être of the memoir.

Despite greatly increased travel opportunities during the second half of the twentieth century, there was no parallel increase in the publication of Australian tales of life in France from these decades. A few accounts are available: a memoir of a cycling trip; a column in a literary journal; three short pieces by literary authors; ${ }^{4}$ and broadcaster Alistair Kershaw's Village to Village: Misadventures in France (1993). Kershaw tells of almost 50 years of living in France, including 20 years in Paris and even longer in the Berry region. This is the only full-length book memoir recounting the sojourn of an Australian in France from the 1990s.

So while Australians certainly travelled to France, even in considerable numbers, throughout the twentieth century, and while quite probably many kept diaries or other accounts of their travels, very little was published recounting the experiences of Australians, and especially 'ordinary' Australians in France. Those that graced the bookshop shelves tended to

residents started to be listed separately in the reports of the Australian Bureau of Statistics, with 8,409 travellers for the year. By the year 2000, France had become the third most common European destination for Australian travellers (50,700 travellers), after the UK and Italy. It has maintained this position, with an average of 12,000 Australian residents per month leaving for short-term travel to France in 2019 (Australian Bureau of Statistics 2019).

2 Diaries of World War I diggers, held by the Australian War Memorial and Australian libraries, have been anthologised by Jonathan King (2008), and Richard White (1987) has analysed the travel they recount, while Rosemary Lancaster (2008) has examined Australian nurses' diaries from the same period. See also Christine Morrow's 'Abominable Epoch' (1972), the privately published diary of her trek through France when she found herself swept up in the exodus of 1940.

3 Artist Stella Bowen's Drawn from Life (1941) is partially set in France; The Rae Johnstone Story (1958) recounts the celebrated jockey's adaptation to the refined milieu of thoroughbred racing in France and in England; and writer and painter Gael Elton Mayos trilogy of memoirs (The Mad Mosaic 1983; The End of a Dream 1987; Living with Beelzebub 1992) recounts her wartime escape from France, and her later life and career in France and elsewhere. Although Australian by birth, Gael Elton Mayo lived in Australia for only one year before being taken to America, and later sent to school in Europe.

4 Trial by Tandem (1950) is artist and critic Alan McCulloch's account of cycling through France and Italy with his wife. A regular column by Robert S. Close, 'An Australian in Paris', appeared in 1954-55 in The Australian Journal, a literary publication primarily focused on serial fiction. Tim Winton's 'The Truly Lousiest Christmas' (1989), and Marion Halligan's 'Aligot' (1994) and 'Toujours Severac' (1997) were set in France. 
be accounts of the extraordinary achievements and lives of distinguished authors or the extraordinary times in which they were living. By the end of the century, however, that pattern was about to change.

Mary Moody's Au Revoir: Running Away from Home at Fifty made waves in 2001 with its candid tale of abandoning family and job to spend six months living alone in a small French village. It was quickly followed by Sarah Turnbull's Almost French: A New Life in Paris, which dominated Australian bestseller lists for 2002, outselling all non-fiction bar the Guinness Book of Records. Suddenly the floodgates were opened. Any scarcity of French memoirs has been more than remedied since the year 2000: over 30 book-length memoirs of Australians in France appeared in the first decade of the century, with eight published in 2008 alone, and the flow continues with more than a dozen since then. And while some of the authors, like gardening show presenter Mary Moody and cook Stephanie Alexander, were already well-known for other achievements, most were not. For the majority of the authors, the French memoir was their first book, France being the selling point, rather than their career or reputation in other fields.

Table 2.1: Book-length commercially published memoirs of time spent in France by Australian authors, 1990-2017.

\begin{tabular}{|l|l|l|l|l|}
\hline Author & \multicolumn{3}{|c|}{ Date } & Title \\
\hline *Kershaw & Alister & 1993 & Village to Village: Misadventures in France \\
\hline Moody & Mary & 2001 & Au Revoir: Running Away from Home at Fifty \\
\hline Hammond & Sally & 2002 & Just Enough French \\
\hline Turnbull & Sarah & 2002 & Almost French: A New Life in Paris \\
\hline Alexander & Stephanie & 2002 & Cooking \& Travelling in South-West France \\
\hline Moody & Mary & 2003 & Last Tango in Toulouse: Torn Between Two Loves \\
\hline Holdforth & Lucinda & 2004 & True Pleasures: A Memoir of Women in Paris \\
\hline *Lawrence & Christopher & 2004 & $\begin{array}{l}\text { Swing Symphony: Another Midlife Adventure in the } \\
\text { South of France }\end{array}$ \\
\hline *Baxter & John & 2005 & $\begin{array}{l}\text { We'll Always Have Paris: Sex and Love in the City } \\
\text { of Light }\end{array}$ \\
\hline Moody & Mary & 2005 & $\begin{array}{l}\text { The Long Hot Summer: A French Heatwave and } \\
\text { a Marriage Meltdown }\end{array}$ \\
\hline Biggs & Barbara & 2005 & The Accidental Renovator: A Paris Story \\
\hline Taylor & Henrietta & 2005 & $\begin{array}{l}\text { Veuve Taylor: A New Life, New Love and Three } \\
\text { Guesthouses in a Small French Village [alternative } \\
\text { title: Escaping] }\end{array}$ \\
\hline
\end{tabular}




\begin{tabular}{|c|c|c|c|}
\hline \multicolumn{2}{|l|}{ Author } & \multirow{2}{*}{$\begin{array}{l}\text { Date } \\
2005\end{array}$} & \multirow{2}{*}{$\begin{array}{l}\text { Title } \\
\text { How to be French }\end{array}$} \\
\hline Ambrose & Margaret & & \\
\hline Archer & Vicki & 2006 & My French Life \\
\hline Bagwell & Sheryle & 2006 & $\begin{array}{l}\text { My French Connection: Coming to Grips with the } \\
\text { World's Most Beautiful but Baffling Country }\end{array}$ \\
\hline Lewis & Elaine & 2006 & Left Bank Waltz: The Australian Bookshop in Paris \\
\hline *Downes & Stephen & 2006 & Paris on a Plate: A Gastronomic Diary \\
\hline Hammond & Sally & 2007 & $\begin{array}{l}\text { Pardon My French: From Paris to the Pyrénées } \\
\text { and Back }\end{array}$ \\
\hline${ }^{*}$ Corbett & Bryce & 2007 & A Town Like Paris: Falling in Love in the City of Light \\
\hline Nielsen & Ellie & 2007 & $\begin{array}{l}\text { Buying a Piece of Paris: Finding a Key to the City } \\
\text { of Love }\end{array}$ \\
\hline Williams & Nadine & 2007 & From France with Love: A Love Story with Baggage \\
\hline *Davis & Tony & 2007 & F. Scott, Ernest and Me \\
\hline Webster & Jane & 2008 & $\begin{array}{l}\text { At my French Table: Food, Family and Joie de vivre } \\
\text { in a Corner of Normandy }\end{array}$ \\
\hline Taylor & Henrietta & 2008 & Lavender and Linen \\
\hline McCulloch & Janelle & 2008 & $\begin{array}{l}\text { La Vie Parisienne: Looking for Love-and the } \\
\text { Perfect Lingerie }\end{array}$ \\
\hline Cashman & Maureen & 2008 & Charlie and Me in Val-Paradis \\
\hline *Baxter & John & 2008 & $\begin{array}{l}\text { Immoveable Feast: A Paris Christmas } \\
\text { [alternative title: Cooking for Claudine] }\end{array}$ \\
\hline Rickard & Ann & 2008 & Ooh La La! A French Romp \\
\hline Raoul & Marisa & 2008 & Ma Folie Française (My French Folly) \\
\hline Coulson & Carla & 2008 & Paris Tango \\
\hline Archer & Vicki & 2009 & $\begin{array}{l}\text { French Essence: Ambience, Beauty and Style } \\
\text { in Provence }\end{array}$ \\
\hline Stafford & Shay & 2010 & Memoirs of a Showgirl \\
\hline Paech & Jane & 2011 & A Family in Paris: Stories of Food, Life and Adventure \\
\hline *Baxter & John & 2011 & $\begin{array}{l}\text { The Most Beautiful Walk in the World: A Pedestrian } \\
\text { in Paris }\end{array}$ \\
\hline Asher & Sally & 2011 & Losing It In France: Les Secrets of the French Diet \\
\hline Webster & Jane & 2012 & French Ties: Love, Life and Recipes \\
\hline *Bennett & Shannon & 2012 & $\begin{array}{l}28 \text { Days in Provence: Food and Family in the Heart } \\
\text { of France }\end{array}$ \\
\hline Cutsforth & Susan & 2013 & Our House is Not in Paris \\
\hline *Baxter & John & 2013 & $\begin{array}{l}\text { The Perfect Meal: In Search of the Lost Tastes } \\
\text { of France }\end{array}$ \\
\hline Raoul & Marisa & 2013 & Club Mauranges: Ma Deuxième Folie \\
\hline
\end{tabular}




\begin{tabular}{|l|l|l|l|}
\hline \multicolumn{2}{|l}{ Author } & Date & Title \\
\hline Cutsforth & Susan & 2014 & Our House is Certainly Not in Paris \\
\hline Cutsforth & Susan & 2015 & Our House is Definitely Not in Paris \\
\hline Miller & Patti & 2015 & Ransacking Paris: A Year with Montaigne and Friends \\
\hline Williams & Nadine & 2017 & Farewell My French Love \\
\hline Lawrence & Katrina & 2017 & Paris Dreaming \\
\hline
\end{tabular}

Source: Author's summary.

Note: Shaded rows indicate sequels; asterisks indicate male authors.

The list in Table 2.1 includes only commercially published book-length memoirs by Australians of their time in France, which comprise the primary corpus of this study. It does not include self-published books, memoirs where France is only one of several European destinations, ${ }^{5}$ parodies of the genre, travel guides without an autobiographical focus (including further books by Janelle McCulloch and John Baxter), fictional narratives, shorter memoirs or travel blogs. The boom in the memoirs is amplified by the numerous Australian examples from these neighbouring genres.

Not only the number of books, but the gender of the authors is striking, for these memoirs are overwhelmingly women's stories. As Figure 2.1 shows, of the memoirs published between 2000 and 2017, more than three-quarters were penned by women ( 25 of the 31 authors). With a disproportionate amount of pink ink on the covers and spines, they are also clearly marketed to women.

5 The self-published Australian memoirs of France include Sharon Stratford's My French Desire (n.d.), Bill Ramson's Seven French Summers (2009) and Hedley Galt's Finding Paris: An Unusual Love Story (2013). Memoirs where France figures prominently but is only one of several destinations include Monica Geti's The Year of Sunshine (2002), Katrina Blowers's Tuning Out: My Quarter-life Crisis (2007), Rina Huber's Nine Summers: Our Mediterranean Odyssey (2007), and Jane de Teliga's Running Away from Home: Finding a New Life in Paris, London and Beyond (2014). 


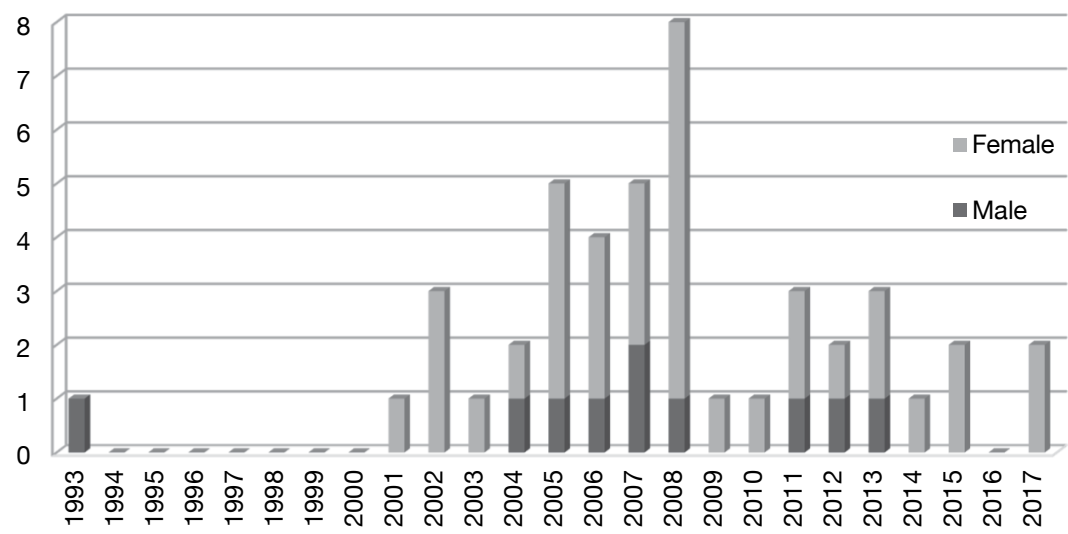

Figure 2.1: Book-length memoirs of Australians in France published 1990-2017, male and female authors.

Source: Author's summary.

The runaway success of Peter Mayle's A Year in Provence (1989), which sold over 5 million copies, was translated into 22 languages and was adapted into a television series (Kneale 2009, 1), was clearly the catalyst for a spate of publications throughout the English-speaking world. Mayle's story of his comic adventures while renovating a house in the south of France, of slowing down and living the good life, quickly became a template for the genre. But a quarter of a century has passed since $A$ Year in Provence first appeared, and the genre has evolved in a variety of directions. Its repeated realisation among Australian authors reveals particular patterns and these patterns are gendered quite differently from Mayle's tale and centre on other concerns. They point to a persistent impulse to tell other versions of the story of life in France.

Since the turn of the millennium, a particular set of stories involving living in France has taken hold of the Australian imagination, and has been supported not only by the publishing industry, but increasingly by niche travel, real estate, homeware and lifestyle enterprises that promote and allude to it through taglines such as 'Learn French, live French' and 'Dreaming of France? So are we'. ${ }^{6}$ Indeed entire Australian businesses are given over to urging us to live a French life, whether through residing in France or adapting our lifestyle.

6 These are the slogans of the Alliance Française Adelaide (www.af.org.au) and French Affair (www.frenchaffair.com.au) respectively (retrieved 22 Sept 2014). Further examples include French Desire (www.frenchdesire.com.au), My French Life (www.myfrenchlife.org), Comme en France (www.comme-en-france.com) and French Moments (www.frenchmoments.eu). See de Nooy (2017) for analysis of the online invitation to Frenchness and its uptake. 
This is not to say that the experience of France is monolithic - there are certainly tensions among the narrative uses of France-but even those authors who challenge the dominant representations of France and Frenchness feel the need to engage with them in their rewriting of the Australian-in-France story. The thirst for this genre of narrative shows no sign of being slaked, and the aim of this book is to tease out its implications. What desires prompt the insistent retelling of the Australian-goes-toFrance story in the twenty-first century? What identifications underpin the compulsion to keep writing and reading its variations? How are these desires and identifications gendered? And what does this particular trajectory-from Australia to France-provide or enable? Indeed, what does travel have to do with it?

\section{Just another sign of the allure of France?}

Some might say that the torrent of memoirs is merely part of a worldwide fascination with France, reflected in tourist numbersFrance is the world's leading tourist destination ${ }^{7}$-and the market for French luxury goods. France has indeed succeeded in branding itself as world leader in elegance and taste, a success that Joan DeJean (2005), in The Essence of Style: How the French Invented Fashion, Fine Food, Chic Cafés, Style, Sophistication, and Glamour, traces back to strategic decisions by Louis XIV. But while France has global cachet as the capital of style, it plays to travellers' sensibilities in culturally specific ways. The global popularity of travel to France and its image as food and fashion capital of the world do not in themselves explain the local and historical inflections of the myth of France, the particular fashioning of the dream of life in France by successive waves of travellers and expatriates from around the world. From the Bohemian artist's garret in Montmartre to the trendy apartment in the Marais district to the run-down farmhouse in Provence, the visions vary. Rather than assuming from the outset a shared fantasy of France, a projection of Paris common to all, this book examines in some detail the refraction of the myth of France through an Australian lens and its prismatic effects.

$7 \quad$ France has not shifted from its position at the top of the ranking of international tourist arrivals during the period studied (World Tourism Organization 2018 and preceding editions). 
There is no lack of discussion of the fascination with France in other contexts, particularly American ones. A great deal has been written about the 'Lost Generation', the American expatriate writers of the 1920s who gathered in post-war Paris. Another sub-culturally specific analysis is undertaken in Why France?: American Historians Reflect on an Enduring Fascination (Downs and Gerson 2007), in which members of a profession discuss their focus on France in autobiographical essays. And Marcy E Schwartz teases out the distinctive ways in which Paris resonates for Latin America in Writing Paris: Urban Topographies of Desire in Contemporary Latin American Fiction, writing that 'Paris is evoked by writers and intellectuals as a metaphor for a broad spectrum of culturally bound desires' $(1999,1)$. The range of ways in which the vision of France is inflected can be seen in the anthology France in Mind (2003). Here, editor Alice Powers has assembled writings about France by 33 British and American authors from Tobias Smollett and Thomas Jefferson to Joanne Harris and David Sedaris. Immediately obvious is the fact that they do not all have the same France in mind. As Powers comments, 'travelers in France are heavily freighted with the weight of home' (2003, xxii). The origin of the journey shapes its destination and, throughout this book, the origins in question, although varied in terms of locality, family and age, will involve an upbringing half a world away from France, in Australia. So while my analysis of Australian memoirs of France will certainly find echoes in British and American memoirs, its focus is firmly on the memoirs emanating from and largely addressed to the inhabitants of a country with a different geographical, historical and cultural relationship to France, memoirs relating to a quite different trajectory-both spatial and in terms of identity. Life in France may not be an exclusively Australian dream but the Australian versions of the dream do not simply replicate those of other travellers.

The dream of France is contiguous with, but not identical to, a certain dream of Italy, so it is not just by chance that the recent flow of memoirs of France is paralleled by a stream of memoirs of Italy. Roberta Trapè lists 22 such books in a footnote to her Imaging Italy through the Eyes of Contemporary Australian Travellers, but prefers to analyse the work of more literary Australian writers $(2011,16)$. Australian impressions of Italy have already been the object of considerably more analysis than those of France, with at least three books devoted to the topic (Prampolini and Hubert 1993; Kent, Pesman and Troup 2008; Trapè 2011) as well as numerous articles. But once again, all Mediterranean destinations are not the same, and the history of Italian migration to Australia colours the relationship 
between the countries in particular ways, such that even Australian tales of olive groves in Italy do not simply coincide with those set in France, such as Vicki Archer's My French Life.

Nonetheless, clearly the proliferation of the Australian French memoir is part of a wider publishing phenomenon, wider in terms of both origin and destination of the author. The Australian memoirs sit on the same bookshop shelves as those-vast in number-by British and North American authors, such as Carol Drinkwater's The Olive Farm and Adam Gopnik's Paris to the Moon. They are intermingled with memoirs of Australians in Italy (Carla Coulson's Italian Joy, Isabella Dusi's Vanilla Beans and Brodo) and those by Anglophones set elsewhere around the Mediterranean, including Frances Mayes' Under the Tuscan Sun. The surge in memoirs is also a product of wider trends in the evolution of life writing generally, with the rise in interest in the lives of 'ordinary' people and in memoirs of personal growth transforming travel writing. Only slightly further along the shelf is Elizabeth Gilbert's Eat, Pray, Love: One Woman's Search for Everything across Italy, India and Indonesia. Online bookshop recommendations for those interested in the Australian memoirs lead quickly to adjacent genres: travel guides, cookbooks, diet and lifestyle books, fiction, humour and self-help. ${ }^{8}$

Australian memoirs of life in France may not be a unified genre, sharply distinct from its American and British counterparts, from memoirs of travel to Italy, or fictional tales of moving to Paris. Many of the Australian memoirs themselves participate in other genres, by including recipes, history lessons, shopping guides or travel tips, or through their formseveral are luscious coffee-table editions complete with exquisite photos and layout. Nonetheless, the Australian French memoirs are worth examining as a group, however fuzzy the edges of this group may be. For we shall see that not only do they reveal antipodean visions of France, but equally they throw light on understandings of Australia. The move to France and the transformation of the self that the author tells of undergoing in the process highlight aspects of Australian life that are otherwise not obvious, in particular issues of gender and identity among Australian women, issues brought into relief by the geographical displacement.

8 For French-themed examples of these genres, see Jean-Benoit Nadeau and Julie Barlow's Sixty Million Frenchmen Can't Be Wrong: Why We Love France but Not the French, Wini Moranville's The Bonne Femme Cookbook: Simple, Splendid Food That French Women Cook Every Day, Mireille Guiliano's French Women Don't Get Fat, Stephen Clarke's A Year in the Merde, David Sedaris's Me Talk Pretty One Day, and Pamela Druckerman's French Parents Don't Give In: 100 Parenting Tips From Paris. 
But before delving more deeply into the pages of the Australian-in-France books, it is worth situating them in relation to what has been written about other clusters of Anglophone memoirs of Mediterranean countries.

\section{Anglophones in the Mediterranean: Defining the subgenre}

Peter Mayle is said to have started it all, with his bestselling $A$ Year in Provence encouraging others to pen their tales of adapting to a life of sunshine and long lunches, and the eccentricities of the local French people. Certainly there were forerunners among the travel memoirs of an earlier age: Kneale notes that 'The form can be seen as having its roots in 18th- and 19th-century travel writing' $(2009,1)$ and cites Lady Winifred Fortescue's Perfume from Provence (1935) as a precursor. Nonetheless, Mayle's memoir marked a new beginning, creating an appetite among readers for this kind of story. The growth in publications was already attracting attention by the turn of the century. In 2000, Australian reviewer Delia Falconer described the 'villa book':

there is a man; he is English, middle-aged, recently retired from a career in advertising and likes to eat in restaurants. Or there is a woman, American, a professor of creative writing, who has travelled to this Latin country many times before and always longed to live here. And there is a villa on a hill [...]. It is love at first sight. (5)

Her characterisation goes on to include the renovation, the markets, the colourful local inhabitants, the adaptation to a slower pace of life. But if Falconer characterises the author as English or American, and equally likely to be male or female, that was because, as Paul Genoni remarks (2007, 214), in the year 2000 there were as yet very few examples of Australian versions of these books. Meanwhile the American realisation of the genre was considerably more established: in 2003 Edward C Knox was able to identify at least 20 personal narratives recounting attempts by Americans to belong at some level in France (2003a, 95), and half of those cited are from the 1990s. He claimed their status as 'a full-fledged genre', which he dubbed 'accommodation literature' (95). These books, concerned with attempts to participate in French culture, he distinguishes from those of 'short-termers [...] fixated on dogs, smoking, women's scarves, allegedly rude waiters and crazy drivers' (107). Knox further divides the accommodation literature into three categories, according to the cultural 
project their authors focus on: 'mastering French cooking [...]; learning French and/or being a student in France; redoing a house and if possible creating a home' (96). He excludes a fourth thematic category-manuals for understanding French culture-and also excludes chronicles of one's Paris years that do not involve some form of intercultural accommodation. Elsewhere, Knox labels the same set of writings as 'sojourner texts' (2003b, 28), sojourners being:

writers who know in advance their time in France will be limited, and so situate themselves between the willed mobility of tourists and travelers on one hand and the deracinated identity of expatriates and exiles on the other. (2003b, 14)

Sojourners or 'accommodationists' write about 'commercial transactions, uninvited guests, the French civil service and just making things work' (2003a, 107). Other standard motifs include alcohol, boules, the Mistral and the importance of history (102). Knox's various distinctions and exclusions indicate that the body of American life writing about France is very extensive indeed, 'with upward of 50 novels, personal narratives, and sets of essays published in the last 10 to 15 years' $(2003 \mathrm{~b}, 12)$.

In 2009, two articles in the Financial Times marked the 20 years since the publication of $A$ Year in Provence by further attempting to define the genre. Matthew Kneale (2009) labels it 'the idyll memoir', and credits Mayle's book with 'establish[ing] memoirs of life in sunny idylls as an important literary genre'. In doing so, he geographically locates both author (in rustic Mediterranean destinations) and implied reader (seeking solace during a northern European winter):

One of its main purposes is to offer readers a little written sunshine for dark winter evenings. To do this, it must convey a sense of its chosen sunny place, the smells and foods and, most of all, the inhabitants, as time gently passes with harvests and house repairs. There is room for a catastrophe or two-a bushfire, perhaps, or a flood-but nothing too disastrous, as this will make the rest seem suddenly rather pale. It should tell stories. Most of all, it must be funny, as without humour those accounts of roof-fixing, grape-picking and olive-squashing will get very tiresome indeed. $(2009,1)$ 
Following Mayle's lead, the common plot tends to consist of 'finding a house, fixing the roof, working out how things are done, meeting bizarre neighbours' (Kneale 2009, 3). Donald Morrison $(2009,15)$ dubs the genre 'let's-move-to-France books' and notes that British publisher Summersdale has developed an entire arm dedicated to publishing them.

The above characterisations of the Mayle-inspired genre reveal general trends and themes among Anglophone authors, but already, through Knox's focus on American examples and Kneale's and Morrison's on British ones, we see differences emerging according to country of origin. Sunshine and relaxation are recurring themes for the British who travel to the south of France for a slower pace of life. Meanwhile, the American themes are divided between sensuous experiences in rural settings and intellectual endeavours in Paris (Knox 2003a, 96).

How then do the Australian iterations of the genre situate themselves with regard to these patterns? For Australians, a move to France is unlikely to be the response to a yearning for sunshine. On the contrary, far from being impressed by French skies, the Australian memoir authors regularly complain of feeling deprived of warmth and sunlight. They find themselves 'longing for light in winter' (Turnbull 2002, 168) in 'sun-starved Paris apartments' (Stafford et al. 2010, 373) under an 'ominous steely grey' sky where the cold is 'brutal and relentless' (J McCulloch 2008, 216), their breath 'imitating a dry ice machine at a second-rate rock concert' (Davis 2007, 279) while they 'dream of sunshine on the bright blue of Sydney harbour, with lots of little white sails bobbing on its sparkling waters and people sunbaking at Nielson Park' (Lewis 2006, 220), and go to extraordinary efforts to find an apartment with a little 'piece of sky' (Nielsen 2007, 142; cf. Turnbull 2002, 232). As Sonia Harford writes when the sky darkens, 'What is it with Australians, that we suffer so much from light deprivation?' (2006, 25). Quite simply, the dream of the 'sunny south' does not resonate with Australians, for whom France in general is perceived as a northern and often chilly destination. It is telling that the only Australian author to mention the sun in the title of her Mediterranean memoir is Monica Geti (2002), who immigrated to Australia from England as an adult. This difference is not as trivial as it may sound: it means that Australians are unlikely to view a stay in France

9 Eduardo Moyà Antón (2013) analyses the importance of late nineteenth-century and early twentieth-century British travel writing about the Mediterranean in the development of discourses of the 'sunny south'. 
as a protracted summer holiday, as 'fun in the sun' and above all relaxation. Instead, as we shall see, they frequently choose Paris as a destination rather than the south of France, and they often travel determined to apply themselves conscientiously to achieving something, even when their goal is to live a simpler life.

But neither do the Australian memoirs simply mirror the American ones. Where Knox identifies clusters of authors who achieve a sense of belonging in France through a project involving cooking, language learning or home renovation, we shall see that the major project undertaken by many of the Australian authors is a renovation of oneself. More obviously, as mentioned already, there is a striking difference where gender is concerned: while men and women figure equally among the American authors that Knox (2003a) cites (and indeed among the British authors cited by Kneale 2009 and Morrison 2009), and while two-thirds of the British and American authors anthologised in France in Mind (Powers 2003) are male, by far the majority of the Australian authors are women. This imbalance is noted by Paul Genoni, who comments that the gender asymmetry seen among the Australian authors is not nearly so apparent on the international publishing scene:

where a review of the most high profile of such books reveals that it is likely that women authors are in the majority, but for every Annie Hawes, Carol Drinkwater or Sally Loomis, there is also a Jeffrey Greene, Chris Stewart or George East. (Genoni 2007, 223)

Genoni's comment appears in a perceptive article entitled 'Unbecoming Australians: Crisis and Community in the Australian Villa/ge Book', in which he draws attention to the rise in Australian memoirs of travel to France and Italy, and discusses some of their commonalities.

\section{Villa/ge books and Tuscan farmhouse literature}

Genoni's is one of a handful of articles that intersect more closely with the concerns of this book, and is the only one to offer a specifically Australian perspective on the genre. Suggesting a correction to Delia Falconer's term 'villa books', Genoni proposes the term 'villa/ge books' to designate the recent spate of Australian memoirs of France, Italy and travel through the Mediterranean. For unlike those Falconer draws on to paint her composite picture of the 'villa book', the Australian memoirs are not necessarily bucolic fantasies. As Genoni points out, they tend to be evenly divided between urban and rural settings $(2007,215)$, with Paris at 
least as popular as Provence or Tuscany as destinations for the Australian memoirists and offering a different version of French life. What draws the books together, according to Genoni, is the quest to find a community, a village rather than a villa, or a quartier — an urban village - to which one can belong in a city. The stimulus for this quest tends to be a personal crisis of some kind, spurring the author to travel.

In contemplating the greater number of women authors of the genre, Genoni notes the gradual increase in opportunities for women's travel during the twentieth century, leading to new feminine paradigms of travel writing (224; cf. Smith 2001, xiii). He remains perplexed, however, at the extent of the gender imbalance among Australian authors. He hypothesises a commercial cause: anticipation among Australian publishers of a largely female readership for narratives of resolution of crisis or of romance in exotic locations (223).

Other researchers from Australia also take Falconer's depiction of the 'villa book' as their starting point to discuss Anglophone memoirs of Italy (Alù 2010) and of Italy and Mexico (Duruz 2004). Wendy Parkins, on the other hand, devises her own label: 'Tuscan farmhouse literature' (2004, 257), which emphasises the invariably rural setting of the memoirs of life in Italy. Australian authors are not a particular focus of these articles, and French memoirs are not mentioned. Only Alù focuses on women's writing. These articles, however, together with Falconer's, raise some pertinent issues for analysis of the Australian-women-in-France memoirs. In particular they point to the middle-class privilege of those who buy and renovate farmhouses in Tuscany, and to the contradiction evident in the memoirs between the yearning for a simpler life on the one hand and the conspicuous consumption involved in buying it on the other. Parkins, for example, in 'At Home in Tuscany: Slow Living and the Cosmopolitan Subject', sees the Tuscan memoir as having 'tapped into a contemporary desire to escape from the speed and anomie of global postmodern culture' $(2004,259)$. She identifies among the authors a desire for 'slow living', for authenticity through domesticity—curiously achieved through jetting in and out of Italy. Meanwhile Alù, in 'Fabricating home: Performances of Belonging and Domesticity in Contemporary Women's Travel Writing in English about Italy' (2010), notes the tension between a cosmopolitan middle-class lifestyle and the lure of conventional domesticity implicated in the idealised Tuscan life. Both Alù and Parkins trace the possibility of performing a new self in a foreign setting, of renovating the self through restoring a dwelling. 
Although some of these elements are evident in the Australian memoirs of life in France-the middle-class privilege of the travellers, contradictions between the life they seek and the life they embody, an idealisation of certain forms of domesticity-their realisation is somewhat different. In particular, 'slow living' is not a constant in the books about France (although it is important for Vicki Archer, Jane Webster and Henrietta Taylor), architectural renovation is only occasionally restoration (again for Vicki Archer and Jane Webster), and expressions of belatedness are few. Indeed many of the Australians in France foreground nervous energy, exhilaration and coffee-at-the-counter rather than the sit-down variety as characteristic of their French life. Something more is at stake than a simpler life, something other than or additional to slowing down, and the new self to which many aspire is not a nostalgic rediscovery but a future-oriented project.

The present book takes these analyses and hypotheses as a starting point, and examines closely the alternative forms of subjectivity—and especially female subjectivity - that are said to be enabled through the Australian authors' geographical transplantation. Paying careful attention to cultural specificity, it focuses on the nature and extent of identifications with France and Frenchness in order to understand the cultural paradigms of femininity and gender relations that the move to France brings into play.

\section{Who goes where?}

\section{Who: Snapshot of the authors}

Who, then, are the Australian authors, where do they settle, and what do they write about? Just over half of the 31 authors of the corpus listed in Table 2.1 work or previously worked in the media: as journalists, critics, broadcasters or previously published authors, for whom we can imagine it would have been increasingly difficult to ignore the publishing opportunity represented by a sojourn in France. Several others were teachers prior to going to France, but the remainder worked in diverse sectors. They include two chefs, an office worker, a photographer, a speechwriter, a beauty therapist, a nurse, a dancer, an actress and a flight attendant. 
Unlike some of the contemporary expatriates that Sonia Harford interviews in Leaving Paradise (2006), none of the authors are on overseas postings with their employers. Except for Jane Paech, who finds herself in the role of 'trailing spouse', following her husband who has been posted to Paris, all make a personal choice to travel to France, in some cases as part of a dramatic choice to lead a different life. The move to France could not be said to be a career move for any of the authors except Shay Stafford, who makes the journey on the strength of the offer of a job as a dancer at the Moulin Rouge. For the others, the move is more often thought of as a leave of absence or as a sabbatical from their professional lives. Once in France, although some take on freelance writing, very few (but notably Bryce Corbett, Elaine Lewis and Sally Asher) have anything resembling a regular job. As Morrison (2009) puts it: 'It is, apparently, easier for an expat in France to find a publisher than a job' (15).

Since writing their first memoir of life in France, however, several have converted their French adventure into an ongoing professional activity. Success has encouraged sequels, with Sally Hammond, Henrietta Taylor, Vicki Archer, Jane Webster and Marisa Raoul writing a follow-up, and Mary Moody, John Baxter and Susan Cutsforth each stretching their French memoirs into a multi-volume series-Baxter on an industrial scale with 15 books about France of which four are more obviously memoirs. Many of the books have a commercial tie-in with a dedicated website, promising readers the opportunity to replicate some of the experience of France they depict: Henrietta Taylor and Barbara Biggs rent out the houses and apartment they write about; Jane Webster and Ann Rickard offer culinary tours including cooking classes; John Baxter proposes walking tours in his neighbourhood; and Mary Moody offers all of the above bar the cooking lessons. Meanwhile Sally Asher has turned the insights she shares in Losing it in France into a weight-loss and lifestyle program called 'Thin for Life', and Patti Miller runs memoir-writing courses in Paris twice a year.

The authors of the corpus were born between 1935 and 1975. Their age at the time of writing ranges from early thirties to early seventies, with roughly a third in their forties, the average for this group. Remarkably, all bar one of the authors have Anglo-Australian backgrounds, the exception being Marisa Raoul with an Italian father, although three (Tony Davis, Ellie Nielsen and Katrina Lawrence) mention a French ancestor. This represents an astonishing homogeneity in multicultural Australia. Their social origins are also similar in that almost all come from middle- 
class backgrounds. Sheryle Bagwell, Barbara Biggs and John Baxter stand out from the rest in emphasising their working-class roots. In describing Australian travellers to Italy up until the 1950s, Ros Pesman notes that 'the vast majority of the travellers came from the same social class and background: a provincial, Protestant British-Australian bourgeoisie' $(2008$, 3). Despite the democratisation of travel in the jet age, this demographic continues to produce the greater part of the memoir-writing travellers to France.

With such a large number of books about France competing for shelf space, many of the authors offer an angle, presenting life in France from a particular perspective. Often the theme is culinary, as might be expected. John Baxter, for his fourth French memoir (2013), decides to imagine the menu for the perfect meal, and uses this as a pretext for anecdotes and entertaining displays of erudition as he recounts his search through France for each course of the dinner. A few relate to the similarly expected theme of buying and renovating a dwelling. Other angles, however, include the Paris lives of famous women (Lucinda Holdforth); the history of eroticism in Paris (Baxter 2005); language learning (Margaret Ambrose); bringing a dog to France (Maureen Cashman); settling children in Paris (Jane Paech); swing music (Christopher Lawrence); writing a novel (Tony Davis); and even-unusually-analysis of contemporary French society (Sheryle Bagwell). Curiously there are to date no gay-themed Australian-in-France memoirs. And presumably an infinite number of further variations are possible, with yet other aspects of identity, animals, hobbies, professions and penchants serving to set new memoirs apart.

\section{Where: Moving and staying}

For Australians, the charms of France are not concentrated in the south. Although Provence continues to lure them, Paris attracts many more. Four of the authors follow Peter Mayle's lead and lodge in Provence: Vicki Archer, Henrietta Taylor, Ann Rickard and Shannon Bennett, the latter most obviously referencing Mayle with his 28 Days in Provence. Another five choose south-west France-Mary Moody, Stephanie Alexander, Maureen Cashman, Marisa Raoul and Susan Cutsforth-while Christopher Lawrence splits his time between Provence and Languedoc, and Jane Webster buys a château in Normandy. This brings to 11 the number who recount their stay in rural settings. Eighteen, howevermore than half-eschew the provincial countryside in search of a different 
ideal. Not seeking the simple life or a gentler pace, they choose city life in France: 17 in Paris plus Sheryle Bagwell in Lyon. Meanwhile Sally Hammond and Nadine Williams do not settle in one particular corner of France but move from place to place, nonetheless staying with the local inhabitants, and thereby still able to cast their experience as one of living in France.

Although most of these books are categorised as travel writing, relatively few pages are devoted to travel per se. The narratives tend to begin and end in France, and even in one small corner of France, with flashbacks to the decision that led the author there. Genoni points out the ways in which these memoirs differ from classic travel writing, with very little travel or sightseeing recounted, and the emphasis on being in situ (2007, 215-16) and finding a home in a new place (222). To use Theroux's distinction between books about 'getting there' and 'being there' (1989, xiii), these are emphatically books about being there. This was already a defining trait in Peter Mayle's writing (Madden 2004, 138). As Holland and Huggan note:

Mayle's books are travelogues that work to erase their 'travel' status, both by establishing a foreign base that assumes the properties of home and by reversing the conventional traveler's distinction between the temporary guest and the permanent host. (1998, 41, original italics)

Indeed they might better be termed 'relocation memoirs' rather than 'travel memoirs': the writers relate the experience of living in France, not of passing through.

Ros Pesman's analysis of earlier Australian women travellers, Duty Free, found the wives and daughters of the colonial élite travelling to Europe to acquire markers of prestige $(1996,24) .{ }^{10}$ She notes that, from the 1970 s onwards, 'Travel no longer conferred the same privileged knowledge and status as it had in the past' as mass travel made overseas travel increasingly accessible to ordinary Australians (220). The democratisation of travel means that contemporary authors need to assert their position differently. Today, the expedition to France does not in itself distinguish an author's experiences from those of potential readers and merit a book. Rather, the appeal of the genre depends on the writer being able to provide an

10 Harvey Levenstein $(1998 ; 2004)$ traces a similar although less gendered pattern in the history of American perceptions of France and its association with the social élite. 
edge, to assert superior knowledge that is not available to every traveller. The emphasis is therefore on providing an insider's insights, the boutique experience of living day-to-day-though without the daily grindrather than travelling in France or visiting popular sights and attractions (see Chapter 3).

So how long do you need to live in France to count as a sojourner rather than a tourist? The books suggest that it is not so much a question of time as of state of mind. Among the Australian memoirs, the relocation is rarely permanent and not necessarily even long-term or full-time. Several of the authors divide their time between two homes, returning to France annually for several weeks or months at a time (Archer, Biggs, Cutsforth, Moody, Rickard, Webster), but maintaining throughout the rest of the year a life in Australia (or in Archer's case, London) involving such mundane elements as employment and school. Only Sarah Turnbull, John Baxter, Marisa Raoul and Henrietta Taylor appear to live all year round in France with the prospect of continuing to do so by the end of the memoir. And if Peter Mayle set the bar for the length of stay at one year-long enough to describe the rhythm of life through all the seasons-this is far from constituting a standard. The length of the stay that the recent Australian authors recount varies wildly, ranging from two weeks (Nielsen) to 25 years (Baxter). One and a half years is the median time they spend in France before writing a book about it, but a third of these first volumes (10 out of 31) are written from the perspective of someone who has stayed there less than a year, a far cry from Alistair Kershaw who clocked up 48 years of residence before publishing his autobiographical account in 1993.

Even the memoirs with the shortest timeframe, however, still present the travel in terms of relocation or the possibility of doing so. Ellie Nielsen, for example, in Buying a Piece of Paris, gives herself only two weeks to buy an apartment, but the apartment itself represents the promise that Nielsen will continue to spend time regularly, although not continuously, in Paris. Similarly oriented towards a French future is Shannon Bennett, whose 28 Days in Provence are recounted as a possible prelude to an ongoing part-time Provençal life. Meanwhile, for Nadine Williams in From France with Love, the spectre of a permanent move to France with Olivier, her new French partner, hovers over her month in France, and is increasingly perceived by her as more of a threat than a promise. The limit case would have to be that of Sally Hammond, whose Just Enough French (2002) recounts her month traversing France with her photographer husband 
and her few words of French. Hammond has decided to stay in chambres d'hôtes (bed and breakfasts) rather than hotels, and often two nights rather than one. Making 'the effort to stay in their homes and put your feet under their tables', she affirms, enables her to get to know French people and gives her a more authentic experience of French life (8). This allows even Hammond to present her experience as living in France rather than merely travelling through it.

\section{What's travel got to do with it?}

Travel is a matter of traversing distance, a distance far from negligible in the case of Australians travelling to France. Conveniently ignoring New Zealand, as they are wont to do, Australians may lay claim to living furthest from France of any nation. There are obvious practical implications to living in the Antipodes: while Londoners can travel to Paris for the day, and New Yorkers can jaunt over for a long weekend, finances permitting, travel from Australia's east coast means a minimum of 21 hours flight and a time difference of eight to 10 hours. Jetting off to Paris for a week is conceivable, indeed not uncommon for Australians attending conferences or on business trips, but there is no escaping the fact that France is less accessible for Australians than for most other Anglophones, that it is literally on the other side of the earth.

It is curious then that getting there, actual travelling, is scarcely narrated in the corpus. Clearly the books are predicated on travel but, as mentioned earlier, it is 'being there' that provides the material for narrative development. The emphasis is on memoir over travel. Place nonetheless remains a decisive element, as Gillian Whitlock explains when she speaks of reading travel memoirs through the lens of life writing:

To read travel writing in terms of autobiographics is to sharpen the focus on the production of the self in these texts, to think about how the writer might invent herself in relation to place. $(2000,77)$

Here place is seen as shaping the imagination of the self. The nexus of self and place can, however, also be viewed from the opposite angle, in order to think about how the writer might invent place, France in this case, in relation to the self. Dennis Porter takes this perspective in Haunted Journeys, suggesting that 'a foreign country constitutes a gigantic Rorschach test' onto which travel writers may project their fears and 
fantasies $(1991,13)$. And Tim Youngs widens the angle from individual writers to encompass their culture when he writes that 'travel writing is more reflective of the society journeyed from than of the country apparently written about' $(1997,119)$. A certain circularity appears: the self is re-imagined in relation to a France that is in turn a projection of the former self; the construction of France and the construction of the self occur in tandem. Both place and self will remain in focus as the following chapters trace these mutually constitutive processes.

Although not recounted at length, travel nonetheless plays a defining role in the memoirs, for the distance it bridges is productive of dreams, plans, escapes, homecomings, indeed all manner of imaginings and adventures. Contingent on travel, the memoirs are the product of a tension between here and there, between a time when 'here' was Australia and France was 'there' and a time when those relations were inversed. Distance and travel provide the enabling conditions for being there, prompting the authors to recount details of everyday life that would otherwise be banal: buying bread, greeting shopkeepers, sitting in cafés.

What then is the importance of being there? Does being there hold the key to understanding the popularity and the proliferation of these memoirs? These questions are the springboard for the following chapter. Certainly, presence lends authority and authenticity to the accounts of life in France, and an opportunity for the authors to demonstrate insider experience and a degree of belonging. But close examination reveals that this is not the whole story, that being there plays a paradoxical role in the telling of the insider's story. What then does being there have to do with it? 
This text is taken from What's France got to do with it?: Contemporary memoirs of Australians in France, by Juliana de Nooy, published 2020 by ANU Press, The Australian National University, Canberra, Australia.

doi.org/10.22459/WF.2020.02 